\title{
A tecelã de intrigas
}

\author{
JOAQUIM BRASIL FONTES \\ Departamento de Metodologia de Ensino \\ Faculdade de Educação \\ Universidade Estadual de Campinas
}

\begin{abstract}
RESUMO: Como um moribundo, a Poetisa dirige-se à divindade

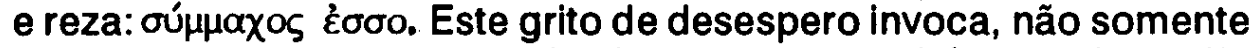
a aliada, palavra de certo modo abstrata, mas também, e sobretudo, aquele (aquela) que assiste alguém em um combate, e convida-nos a reler um poema de Safo (mais conhecido sob o nome de Ode a Afrodite) através da trama do léxico dos combates: presa na tessitura do canto, Afrodite avança, no campo de batalha, ao lado do enamorado.
\end{abstract}

PALAVRAS-CHAVE: Safo, Afrodite, Ifrica grega, literatura grega, Grécia.

Ninguém chega a produzir muita poesia digna de nota: isto é, no cômputo geral, ninguém produz muita coisa que seja definitiva, e quando não está fazendo essa coisa suprema, quando não está dizendo algo com perfeição e de uma vez por todas; quando não está acomodando moıkı $\lambda o ́ \theta \rho o v ~ a ̈ \theta \alpha v \alpha$ " "A $\phi \rho o ́ \delta ı, T \alpha$, ou "Hist said Kate the Queen", ser-lhe-á muito proveitoso fazer os tipos de experiência que lhe poderão ser úteis em sua obra posterior, ou aos seus sucessores [Pound, 1976: 18].

Ezra Pound refere-se, nesta passagem dos Ensaios, a uns versos gregos que vêm sendo, há dois milênios e meio, comentados, parafraseados e traduzidos no Ocidente: a Ode a Afrodite, a única das poesias de Safo de Lesbos que ainda podemos ler na íntegra, graças a uma citaçāo num pequeno tratado de estilística composto - acredita-se - um pouco antes do nascimento de Cristo ${ }^{1}$. $O$ autor do livrinho, Dionísios de Halicarnasso, heleno da Ásia Menor, encanta-se, tanto quanto o poeta inglês, diante do texto, já velho, para ele, de seiscentos anos; e maravilha-se com as palavras que "se justapōem e se tecem de acordo com certas afinidades naturais e agrupamentos de letras". "Um conjunto fluente, coeso, eufônico": perfeito, de uma vez por todas.

Esses elogios podem parecer excessivos quando, esquecido o texto grego, entramos em contato com as imitações ou traduções que atravessaram o poema; a tal ponto que ele parece ser a cópia, o reflexo dele mesmo: palavras cheias de 
imagens conhecidas e de nomes banais - Afrodite ou Amor... Na memória dos bons estudantes de letras, ecoam os versos da adaptaço feita por Garrett ${ }^{3}$ :

Filha de Jove, que tens altares

Em cem lugares, Diva falaz:

Ah! poupa mágoas a quem te adora

A quem implora favor e paz.

Tu já outrora piedosa ouviste

O brado triste da minha voz:

E da paterna mansão celeste

A mim vieste pronta e veloz.

Ao níveo carro jungido tinhas

Das avezinhas o meigo par.

Ele voando pelo ar sereno

Em prado ameno veio pousar.

E tu, sorrindo, de mim diante

Meigo o semblante falaste assim:

"Safo, eu te vejo tāo consternada

Por que magoada chamas por mim?

"Paixāo te oprime? Gemes, suspiras

Dize, a quem aspiras com tanto ardor?

Alguém, ingrato, se te não rende?

Ah! quem te ofende com tal rigor?

"Há de rogar-te, se te ora enjeita.

Teus dons rejeita? Dons te dará:

Desquer-te amado? Por ti já esquiva

Em chama ativa se abrasará."

Também agora, deusa benigna,

A mim te digna dar proteção:

Auxiliadora neste conflito

Vale ao aflito meu coração.

Vagamente decepcionados, deixamos a literatura moderna, voltando os olhos para trás: para o mundo arcaico, tão misterioso em suas ruínas, e onde o poema deverá encontrar seu contexto verdadeiro. Mas constatamos, com uma ponta de surpresa, que a estrutura da Ode a Afrodite difere muito pouco das inúmeras preces que os heróis dirigem, no registro épico, às grandes divindades. Temos a impressão de que as palavras de Safo demarcam, claramente, algumas falas de Aquiles, Diomedes ou Agamêmnon, na Iliada.

Diomedes, ferido por Pândion, chama por Atena ${ }^{4}$ :

Ouve-me, $\delta$ Infatigável, filha de Zeus, o detentor da égide.

Se algum dia, resoluta e amiga, me assististe, a mim e a meu pai,

Faze com que eu mate esse homem, traze-o ao alcance da minha

Ele que me tocou primeiro e disto se ufana, dizendo que eu, lança,

Por muito tempo, não verei a refulgente luz do sol.

[Ilíada V, 115-120] 
Os heróis rezam assim, no mundo épico. Primeiro, é preciso clamar pelo nome do deus, invocado segundo seus epítetos rituais: Infatigável, filha de Zeus... Ao grito, segue-se uma "confirmação" protocolar: o recitante lembra os benefícios recebidos no passado - se algum dia, resoluta e amiga.... -, reafirmando o contrato entre a divindade e o crente, e abrindo o caminho para a súplica: faze com que eu mate esse homem... E a estrutura comum a quase todas as preces da Iliada e, geralmente, elas são fechadas com uma promessa de sacrifícios ou de dons, em paga dos favores obtidos:

... e logo, em teu templo, nós te oferecemos doze vitelas de um ano, que não conheceram o aguilhăo, se te dignares a ter piedade ...

[Ilíada, VI, 308-309]

E Safo de Lesbos, em tradução apenas aproximada:

1. Aphrodite imortal em trono de cores e brilhos, filha de Zeus, tecelã de intrigas! eu te suplico:

Não dobres a tormentos e angústias, 6 Rainha, Meu coração;

5. Mas vem até mim, se jamais no passado

Ao longe ouviste meu grito e atendeste

E do teu pai o palácio deixando,

De ouro, vieste,

O carro atrelando: belos pardais

10. Velozes te levaram pela terra sombria, Asas rápidas, turbilhonando, dos altos

Céus, através dos ares,

E prontamente chegaram; e tu, Bem-Aventurada,

Com um sorriso no teu rosto imortal,

15. Perguntaste por que eu sofria de novo,

E por que de novo eu suplicava,

E o que eu mais queria, na loucura

Do coração, conseguir. Quem, de novo,

Deve trazer a Persuasiva para teu amor? Quem,

20. O Psappho, te contraria?

Pois, se ela foge, logo perseguirá;

Se recusa presentes, presentes ofertará;

Se não ama, logo vai amar,

Ainda não querendo.

25. Agora! outra vez, vem até mim, livra-me

Deste aflito sofrimento; compre os desejos

Que o coração quer cumprir; e torna-te, tu mesma,

Em ajudante-nos-combates.

[Safo, fr.1, in Lobel e Page, 1955]

Percebemos imediatamente as semelhanças, mas também as grandes diferenças que existem entre as palavras de Safo e as do guerreiro. Antes de tudo, o contexto. Diomedes suplica aos deuses no campo de batalha, entre gritos e agonias; a prece é a respiraçāo tensa da palavra, prolongando e anunciando o retinir das armas e o zunir das flechas. Em Safo, uma voz de mulher dirige-se a Afrodite, filha de Zeus, e solicita esta coisa tão banal: o amor de outra pessoa. Um pequeno acontecimento à superfície do mundo, e que nāo exercerá a menor influência sobre 
o curso da história; uma futilidade. A poetisa não é Helena, por quem veio abaixo Tróia de vastas praças, e registra um episódio de sua vida íntima, e ousa convocar, para isso, o grande aparato das declamaçōes épicas: o vocabulário, o ritmo grandioso e opressivo das súplicas. A desproporção entre palavra e evento é muito grande, e vai se aprofundar. Mas, antes de procurar compreender essa contaminação de registros discursivos, observemos outro detalhe que singulariza a Ode a Afrodite quando comparada, por exemplo, à prece do herói.

Dramaticamente, emergindo na memória da Suplicante, a deusa manifesta-se no interior da própria oração; e fala. Um tema raro no mundo grego, mas que de acordo com C.M. Bowra, tinha alguns precedentes ou paralelos (Bowra, 1961, p. 202). No canto I da Ilíada, no instante em que Aquiles está prestes a puxar da espada contra Agamêmnon, Palas desce do céu e intervém na ação. Visível apenas para o herói, a deusa provoca um diálogo e muda o curso dos eventos (Ilíada, I, 194 sq.). Na Odisséia, Atena é a companheira fiel de Ulisses; e, nos momentos estratégicos de seu percurso, ela se manifesta. Não pode ser vista, embora fale e aconselhe.

Mas, no registro épico, o discurso de um narrador sustenta as personagens e suas falas; a teofania acontece no curso de uma história que envolve homens e divindades, e diz respeito ao destino de um povo inteiro. $O$ futuro da Hélade está suspenso às súplicas de Aquiles, Agamêmnon ou Diomedes. Na lírica de Safo, a deusa do amor se manifesta no interior das palavras do orante: na força da memória. Esse acontecimento diz respeito apenas à vida de uma mulher apaixonada por outra, cujo nome nem sequer sabemos. Isso pode ser, afinal de contas, alguma coisa de muito novo, no mundo grego. Talvez pudéssemos tentar uma análise mais cuidadosa dessas questōes, começando, modestamente, com um rápido estudo dos aspectos "formais".

C.M. Bowra (Bowra, op. cit., p. 204) chama a atenção para o perfeito equilíbrio do texto: os requisitos de uma prece são observados interna e externamente. A Invocação ocupa uma estrofe inteira, no início, e a Súplica outra, no final; as duas enquadram o bloco constituído pela Confirmação. Os temas da submissão e da angústia, modulados na abertura da ode, são retomados e transformados no fecho:

eu te suplico:

Não dobres a tormentos e angústias, ó Rainha,

Meu coração;

solta-me

Deste aflito sofrimento; cumpre os desejos

Que o coração quer cumprir;

Tradução aproximada, já observei ao apresentar os versos em português. Deixando de lado minhas limitaçōes na arte de recriar os ritmos helênicos, há o problema do léxico. É extremamente difícil, admite um dos grandes especialistas modernos de Safo e Alceu (Page, 1955, p. 6-7), determinar com exatidão o significado de alguns termos, já na primeira estrofe. Encontramos certas cadeias fônicas muito melodiosas, mas de sentido um pouco obscuro:

líssomaí se, me m’ásaisi med'oníaisi dámna, pótnia, thymón 
A palavra ơvía (anía), cognata de óvíaı oı (oníaisi), está associada à idéia de

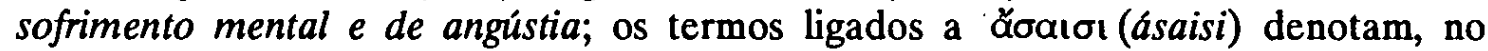
discurso da medicina, desconforto físico. Denys Page descarta, entretanto, a possibilidade de ler no poema, a partir de ăoaı oı, alguma coisa como "náusea" ou "nojo": o contexto, afirma ele, solicita as condiçōes de "afliçāo", "desgosto", "angústia".

Sigamos, provisoriamente, esses conselhos; examinemos a última estrofe. Designada por dois plurais na abertura do poema, a idéia de sofrimento reaparece, no final, através de um singular adjetivado: $\chi \alpha \lambda c_{\varepsilon}^{\pi} \alpha v / . . . / \mu \varepsilon \rho i ́ \mu v a v$ (khalépan/.../merimnan). $\mathrm{O}$ primeiro termo significa: penoso, opressivo, cruel. $\mathrm{O}$ substantivo quer dizer preocupação, ansiedade, inquietação. No mesmo contexto, aparece a terceira pessoa do singular de um verbo significando "desejar": ỉ $\mu$ épeı (imérrei). Todos esses signos têm que ser compreendidos como movimento: ímpeto em direçāo ao passado, ào futuro: na última estrofe do poema, a vontade do poeta: tensa. Page traduz da seguinte maneira os versos 26-27: Fulfil all that my heart desires to fulfil ( Id., ibid., p. 4). E duas vezes repetida, em duas linhas subseqüentes, uma forma verbal que significa "cumprir", "executar", "levar a bom termo": retomada e transformação do esquema de angústia e submissāo, preso, aqui e na primeira estrofe, ao thymós.

Esse termo, que traduzi, de acordo com a rotina, por coração (alguns preferem espirito), indicava, na Grécia arcaica, o princípio da vida. Localizava-se, esta força, no diafragma (phrénes), onde o homem pensa e sente. Diríamos, hoje: o thymós é a paixão e a vontade. Relacionada, etimologicamente, ao latim fumus e a thyo, a palavra sugere, segundo Jaeger, um jorro de sangue quente, e liga-se ao conceito de movimento, "num sentido mais tarde explorado por Aristóteles; so os impulsos do thymós que impelem o herói à atividade" (Jaeger, 1982, p. 85-86; cf. Taylor, 1985, p. 110 sq.).

$\mathrm{Na}$ primeira estrofe do poema, uma súplica: "não submetas, Senhora, o Өụuós à escravidão das paixões". E o que parece indicar a forma dámna (v.3), de um verbo significando "domar" (um animal), "submeter" (uma jovem ao jogo do marido) e, finalmente, "dominar o coração de alguém". Na última estrofe, transformam-se os esquemas sintáticos e semânticos: a possibilidade da libertação existe

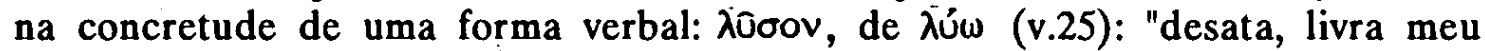
coração destas amarras".

$\mathrm{Na}$ vertigem da agonia, a Suplicante invoca Afrodite. E não sabemos muito bem como explicar a teofania que aconteceu no interior do poema. Um artifício de estilo? Um sonho? Estaria o poeta pensando em alguma imagem sagrada, num santuário? Só comprełndemos que, no passado, a divindade já ouviu seus gritos, em circunstâncias parecidas, e, atrelando o carro com pardais - aves lascivas e fecundas, símbolo do ímpeto vital -, desceu do céu, girou em torno da terra escura e dirigiu à mulher amorosa palavras diretas e simples. Denys Page as analisou com

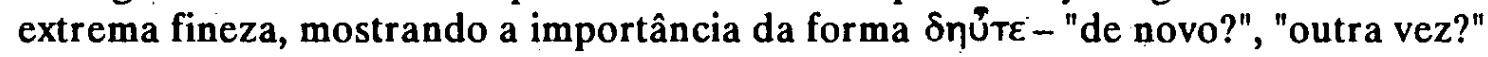
- três vezes repetida, em três frases diferentes: "Por que tu sofres de novo?", "De novo, por que suplicas?", "Quem, de novo, deve a Persuasiva convencer para teu amor?" Repetição contendo, certamente, um sentido, assim como a tríplice oposiçāo, na penúltima estrofe, acentuada pelo advérbio "logo", "em breve":

Pois, se ela foge, logo perseguirá;

Se recusa presentes, presentes ofertará;

Se nāo ama, logo vai amar... 
Aqui, as palavras de Afrodite - a explicação é de Denys Page (Page, op. cit., p. 12 sq.) - indicam uma futura inversão de papéis, no pequeno drama amoroso vivido por Safo: "amanhã, tu, minha Psappho, estarás fugindo da mulher que, hoje, tu persegues". A ação do verbo fugir ( $\phi \varepsilon u ́ \gamma \omega)$ é estreitamente correlativa, em grego, de buscar ou perseguir: amanhã, ela forçará a seduzir; há de ser obrigada a realizar os gestos rituais do amoroso; oferecer, por exemplo, os presentes que, hoje, recusa receber. Reversão do quadro atual. $O$ indiferente vai viver, amanhã, sua própria agonia.

Ao falar, Afrodite sorri. Por quê? Para compreender este momento capital do texto, C. M. Bowra (Bowra, op. cit.), como quase todos os especialistas modernos, adere à explicação proposta por Denys Page (Page, loc. cit.) em seu clássico estudo sobre Safo. O sorriso é um signo de condescendência irônica, um toque de humor.

"Outra vez? Tu me chamas outra vez?" A deusa, segundo as palavras de Page, mostra-se um pouco impaciente, mas tolerante, e se diverte, falando num tom de bem-humorada repreensão: "Por que levar o caso tão a sério? Afinal, podes contar comigo, já que ajudei no passado, bem sabes. Amanhã, a pessoa que amas vai te perseguir, tu estarás fugindo do seu amor e o mundo estará em ordem". Haveria, portanto, uma nota de alegria, de sorridente compreensão entre Afrodite e Safo. "Uma luz", escreve Denys Page, "cai sobre um ponto obscuro do texto".

E verdade que, no Hino homérico, Afrodite recebe o epíteto de Philomeidés, "a amiga dos sorrisos"; nuns versos, entretanto, que a descrevem como Senhora das Feras, seguida por um cortejo de lobos, de leões de fulvo pêlo e de panteras: ela infunde o desejo no coração dos animais, e eles vão se acasalar na sombra dos pequenos vales:

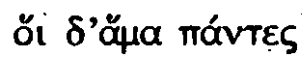

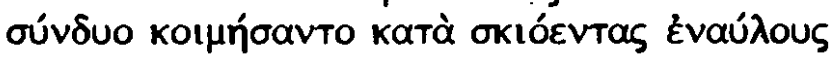

$$
\begin{aligned}
& \text { [Hino Homérico a Afrodite, 73-74] }
\end{aligned}
$$

Seu poder atinge os próprios deuses, as tribos dos mortais, os pássaros que voam e todas as criaturas da terra e do mar: Afrodite é uma força irredutível que une os três reinos: animal, divino e humano. E eu creio que é sob esse aspecto que ela está presente no poema de Safo. Se repararmos nos versos 16 - 17:

... e o que eu mais queria, na loucura do coração, obter,

reencontramos a palavra thymós, articulada a uma forma de querer que escapa ao que chamaríamos, hoje, de racional. O texto grego diz: mainólai thymol, e o primeiro desses vocábulos refere-se à "agitação proveniente de um transporte furioso" - raiva, ou delírio. Nos contextos em que aparece, o verbo $\mu a i ́ v \omega$ aplica-se aos guerreiros, aos homens ébrios ou possuídos pela divindade. Às vezes, é aplicado ao fogo; de qualquer forma, evoca uma força irresistível, que se apodera dos homens e mulheres. A mênade do cortejo de Dioniso é um ser furioso, enlouquecido: maníaco. Habitado por deus, como o amoroso é possuído pelo ímpeto erótico. Ao encontrar a deusa reverberando, no centro exato do poema, sobre a noite da agonia amorosa:

Com um sorriso no [seu] rosto imortal, 
o leitor hesita antes de aceitar a tese de Denys Page sobre a cumplicidade, irônica e "civilizada", entre Safo e Afrodite.

E o mesmo sorriso que aparece nas estátuas arcaicas? Sobre o rosto dos deuses, dos Koúroi vencedores dos torneios atléticos, das Kbrai; nos lábios do Cavaleiro de Rampin... Inabilidade, 'talvez, do escultor, que ainda não dominou as sutilezas de sua técnica. Presente, contudo, séculos depois, nas personagens de Leonardo, o sorriso misterioso das figuras arcaicas não poderia ser, também, um signo? Desenhando, no rosto das imagens, o brilho e o desprendimento - a serenidade absoluta - dos imortais? e daqueles mortais que, por um instante fugaz, escaparam à sua condição:

Criaturas suspensas a um só dia: o que somos?

o que nāo somos? sombra de um sonho,

o homem. Mas, quando a luz de um deus, do alto,

capta no seu resplendor o homem,

o durar do seu dia tem a doçura do mel.

[Píndaro, VIII Pítica, 95-98]

Nesse momento, ele pode ser talhado - sorrindo - no mármore.

Os helenos foram sensíveis à irredutível finitude do homem: precário, fugaz, ele brilha por um instante debaixo da luz do sol, pela mercê dos deuses - lembram uns versos de Mímnermo de Esmirna, do fim do século VII a.C. e logo se esvai. Mas a morte não é consolo: no sombrio Hades, as obscuras almas voam às cegas; é ali que o fantasma de Aquiles, na Odisséia, diz estas palavras terríveis a Ulisses: "Antes ser escravo de um homem pobre e sem recursos do que reinar sobre o povo dos mortos".

"A exuberância extraordinária da alegria (dos deuses)" - escreve André Bonnard -, "no seio da dor do mundo que dirigem, é uma terrível confirmação de sua divindade. (...) Vivem a vida numa plenitude tão total que o crente nada mais pode fazer que adorá-los" (Bonnard, 1980, p. 148). Quando Hipólito, agonizante, suplica pela presença de Ártemis, a deusa bem amada, sua protetora - Tu me vês, $\delta$ Soberana?, -, ela responde: eu te vejo -, e acrescenta: mas aos meus olhos são proibidas as lágrimas -

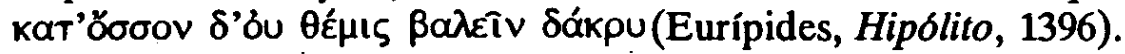

O sorriso de Afrodite ocupa o centro exato do poema, seu ponto nevrálgico; dele partem e para ele convergem sentidos. De um lado, a serena luminosidade dos deuses: imortais, livres dos cuidados e angústias. De outro, a Suplicante, na vertigem da agonia amorosa. Vida e Morte: presas aos lábios de Afrodite.

Tínhamos entrado no poema de Safo um pouco levianamente, como se ele não passasse de uma pequena alegoria mitológica, deliciosa e inconseqüente. $E$ descobrimos, no sorriso de Afrodite, seu poder absoluto. A deusa já havia aparecido sob esse aspecto na Invocação, e não tínhamos percebido. Imortal, em trono de cores e brilhos, filha de Zeus, tecelã de intrigas. Não são apenas epítetos obrigatórios, ou belas sonoridades, ou fórmulas para uso do declamador e do ouvinte que, graças a elas, reconhece imediatamente a personagem de quem se fala (Aubreton, op. cit., p. 83) (são isso também). Afrodite é a deusa do trono cintilante, fulgurante, furta-cor: poikilothron. Palavra, adverte Denys Page, incomum na literatura grega, onde existe poikilóphron ("astucioso"), e onde geralmente se atribuem à deusa do amor epítetos de outro tipo: dos cabelos de ouro, coroada de ouro, Kyprogenés. Em alguns fragmentos de Safo, ela é designada assim: 
l eu falei; num sonho, com a deusa nascida em Kypros [

] Aphrodite coroada de ouro! se eu pudesse obter esse dom

no lance da sorte [

[Safo, frs. 134, 33, in Lobel e Page, op. cit.]

No século $\mathrm{V}$ a.C., uma galeria recoberta de quadros de Polignoto recebe o nome de hè Poikile, "a de cores brilhantes". Em Ésquilo, o orgulho e a desmedida do herói Agamêmnon manifestam-se quando, atendendo à provocaçāo de Clitemnestra, ousa penetrar no palácio, andando sobre magníficos tapetes bordados: tà poikila (Agamêmnon, 936). Essa palavra quer dizer, enquanto adjetivo, "matizado", "mosqueado", "salpicado". Encerra uma idéia de cor e de brilho, em contextos ligados à ourivesaria, à pintura, à arte dos bordados. A tradução que propus: "em trono de cores e brilhos" - não é, sem dúvida, a melhor, mas pode sugerir o esplendor, o altíssimo grau de elaboração técnica do trono de Afrodite: recoberto de trabalhos delicados, cintilante, colorido.

Signo de poder, o epíteto poikilóthron é retomado por outro, seu reflexo fonético e semântico: doloplóke. Tecelā de intrigas, urdidora de tramas, ou de ardis. Dólos é todo objetivo que serve para enganar: armadilha, engodo, isca. $O$ verbo pléko significa "tecer": guirlandas, por exemplo. Ploké é a ação de entrelaçar; ou tecido. Aristóteles utilizará essa palavra na Poética para a intriga da tragédia, ou melhor: o entrelaçar, o "n 6 " dos eventos (1456 a). Eis o que é Afrodite, no poema de Safo de Lesbos: a deusa paciente, que tece com delicadeza suas astúcias e as intrigas amorosas. Na Ética a Nicômaco, citam-se uns versos, mais tarde indevidamente atribuídos a Safo: "... e o desejo, ao contrário, procura enganar, como se diz de Afrodite: a deusa de Kýpros, que urde suas tramas..." (Ética a Nicômaco, VII, 1149 b).

O trono de Afrodite, com suas cores de brilhos instáveis, reflete seu modo de ser: cambiante, astucioso, irisado. Safo diz que a Persuasão é filha de Afrodite - anota o escoliasta de Hesíodo, (Os Trabalhos e os Dias, 74); e debaixo desta máscara, a deusa pergunta nos versos 18,19 do poema:

\section{Quem, de novo, \\ Deve trazer a Persuasiva para teu amor?}

Para os gregos, a arte de seduzir sempre ocupou um lugar importante nas relaçōes de amor: é preciso fascinar o outro - com flores, presentes, palavras. Afrodite preside a essa techné complicada das intrigas eróticas, à tessitura dos discursos matizados. Sua palavra é furta-cor e cintilante, puro íris. As estratégias, nesse domínio, exigem tempo e paciência.

Tem-se a impressão, contudo, de que o amoroso, em Safo de Lesbos, é igual às crianças e aos loucos; para ele, não existem mediações: "tudo, nesse'momento!" E a figura da Impaciência, da Urgência: "Agora, vem até mim, e solta-me deste aflito sofrimento!" "Meus desejos realiza!" Criatura suspensa na hora que foge, ele experimenta, na revulsão do corpo e dó espírito, os limites do humano: no instante mesmo em que é atravessado por um desejo absoluto.

A energia obsessiva dessa vontade palpita em cada signo. Seu contraponto, sua contra-melodia chama-se Afrodite: no centro do poema, ela responde com 
palavras astuciosas: sorrindo. Seu reflexo está presente em cada palavra, em cada verso; com seus auxiliares "I $\Pi \varepsilon ı ̂ \omega ́$ (a Persuasão). Longe de serem elegantes abstraçōes, ou alegorias, eles emergem na essência das ações: na força das palavras gregas. A Persuasiva modula gestos e vocábulos, os epítetos, as formas verbais, a dramatização da penúltima estrofe.

Numa das muitas e curiosas etimologias do Crátilo (420 a), Sócrates ensina

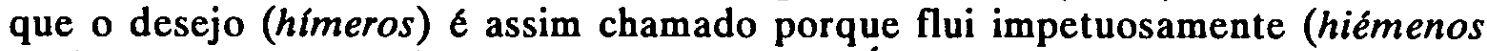
rhê̂) na perseguição (ephiémenos) dos seres. É uma corrénte, um fluxo que se apodera da alma. Existe num presente absoluto: é o contrário, sob esse aspecto, de póthos, desejo - e, portanto, corrente, fluxo - voltado para o que está em outro lugar e ausente. As palavras de Sócrates sugerem que os dois princípios são correlativos: "de onde a denominação de póthos dada ao que se chama de hímeros quando o objetivo está presente". Não se trata de discutir a "fantasia" dessas ligaçōes: elas mostram um grego percebendo, nas palavras e sentimentos, a emergência das forças vitais; e seu ritmo. Elas vibram, no centro da Ode a Afrodite, concentrando, no grito do ser amoroso, uma temporalidade absoluta: o passado (póthos), o presente (himeros), o futuro (peitho). Captados no thymós que, finalmente, podemos compreender através da metáfora do jorro de sangue.

A palavra thymós aparece em três momentos estratégicos do texto, morfologicamente modulada: thymón $(\mathrm{I}, 4)$; thymoi $(V, 18)$; thymós (VII,27), ganhando as irisações a que a gramática tradicional dá o nome de acusativo, dativo e nominativo - figura recuperada, no contexto da retórica, pela elegante denominação de poliptoto (Quintiliano, Institutio Oratoria. X, 3). Em cada uma dessas manifestaçes, aparecem cadeias fônicas e semânticas que se respondem umas às outras:

$\mathrm{Na}$ estrofe I:

líssomaí se,/ me m'ásaisi. med'oníaisi dámna,/ pótnia, thymón (Aos tormentos e angústias não submetas, 'ó Rainha, meu coração)

Na estrofe VII:

Khalépan dè lýson/ek merímnan, óssa dé moi télessai/thymòs imêrrei, téleson: (solta-me deste aflito sofrimento; realiza os desejos que o coração quer realizar:)

Na primeira estrofe o "eu" é captado no movimento da angústia, numa revulsão próxima à náusea. É verdade que os termos ăot e ávíaı são considerados quase sinônimos por Denys Page; eles apresentariam somente uma gradação de intensidade, gênero "heart-ache" e "anguish" (Page, loc. cit.). Embora ásaisi reenvie a um vocabulário de medicina, designando sintomas corporais: vômito, nojo, náusea. Sob esse aspecto, parece opor-se ao termo ávía. Em Hesíodo um verbo cognato - ảviá́c - é empregado num contexto em que há referência ao thymós, e significa os aborrecimentos e as afliçōes, os cuidados provocados pela mulher, 
"desgraça criada por Zeus". Afinal, é possível que os dois termos utilizados por Safo apresentem uma gradação de sentido: talvez apareçam no poema para captar, dramaticamente, a agonia do thymós em seu duplo movimento indissolúvel de vontade e de sentimento, de "pensamento" e de paixão.

Naturalmente, séculos de tradição poética já nos habituaram a ver o amor como sentimento "espiritual": esquecemos de, não queremos ou não podemos admitir que as dores da "alma" se revelam, também, através da náusea e do nojo. Demoramos um pouco a compreender que, na Ode a Afrodite, o amoroso é apresentado na completa revulsão do desgosto físico e moral: aqui não existem "nobres" sentimentos e "baixas" sensaçōes corporais.

No fecho do poema, o radical presente em oniaisi reaparece (um pequeno delírio de interpretação?) nas palavras que significam "aflição" e "desejo" (merimna, imérrei) ${ }^{6}$.E ele surge como ímpeto de libertação; flui, do passado, para uma vontade aberta sobre o futuro. Afrodite será invocada, neste contexto, sob o aspecto de Sýmmakhos, Companheiros-nos Combates.

Entre estes dois momentos fundamentais, a estrofe V: "O que eu mais quero, na loucura do coração, obter...". O desejo, articulado à desrazāo, no momento em que Afrodite, a amiga dos sorrisos, aparece debaixo da máscara da Persuasiva. "Convencer": agir no tempo, contra o tempo; falar seduzindo, para transformar.

No Crátilo (420 a), Sócrates explicava a Hermógenes que o thymós, o princípio vital, deve seu nome ao fato de ser ímpeto, agitação da alma. $O$ registro épico liga também essa palavra à idéia de movimento: é o thymós que impele o herói à açāo.

Em Safo de Lesbos, ele vibra e se entrelaça, num ritmo de dança, a outra forma de energia: o Amor, A deusa, no rapto do corpoalma, avança, compondo o poema na trama do desejo: o sagrado manifesta-se nas palavras e constitui a essência dos versos. Teofania da e na linguagem.

Voltemos a algumas questões de caráter "técnico". Chamando a atenção para o equilíbrio perfeito do poema, C. M. Bowra nota que sua estrutura tripartida pontua com muita sutileza um discurso caracterizado pela fluência: "existe uma pequena pausa no final da primeira, sexta e última estrofes, isto é, da Invocação, da Confirmação e da Súplica. Todo o resto está ligado pela passagem das frases umas nas outras. Quando uma ocupa todo um verso, como o 14:

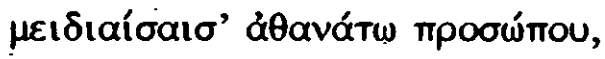

chama nossa atenção, e nós percebemos sua importância. Quando o ritmo de um verso repete o de outro, exatamente, como (21):

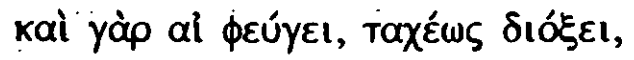

repete (23): 


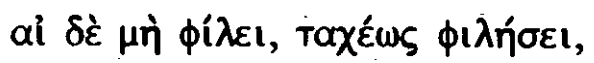

vemos que as promessas são paralelas e apresentadas como tal"(Bowra, op. cit., p. 205).

Essa é uma característica geral da arte arcaica; Fränkel chega a falar numa "lei" da continuidade (Fränkel, 1975, p. 518), regendo um mundo no qual o todo está necessariamente presente nas partes. Em Safo, a harmonia das "palavras constantes" revela-se nos detalhes mais simples. Apenas um exemplo, dizendo respeito às ligaçōes "sintáticas": na falta de Afrodite, a interrogação indireta desemboca na direta sem que haja cortes verbais - desespero do tradutor, obrigado a recorrer às convençôes de seu próprio idioma, e marcar alguns momentos do texto com as aspas convencionais:

Perguntaste (...) o que eu mais desejava obter(...)

"Quem, o Psappho, te contraria?"

Não há ruptura entre esses dois momentos: o primeiro, tanto quanto o segundo, indica um passado (a teofania) presente, como sua própria tessitura, nas palavras do Amoroso; desembocam os dois tempos no grito da última estrofe, tenso para o futuro: "solta-me deste aflito sofrimento!"

$E k$-stásis do passado no presente e no futuro: indicando que a estrutura tripartida do poema não é linear: na Invocação, existe uma Súplica (Não submetas, Senhora, meu coração aos tormentos e angústias); e ela permeia o texto inteiro. Aparece, como passado, na segunda estrofe e, depois, nas palavras da própria deusa. Palavras vindas do passado e abertas para o futuro, através do presente: se hoje ela está fugindo, amanhã perseguirá. $\mathrm{Na}$ amada indiferente, já podemos ler o desenho de um amoroso que implora: inversão de papéis.

Acompanhando a Súplica, a Invocação está disseminada ao longo das estrofes: na palavra imortal do v.14; na tecelâ de intrigas presentificada em seu agir; e projeta-se nos versos finais: onde Afrodite recebe um novo epíteto - Companheiro-nos-Combates (Sýmmakhos).

Correspondendo a um nome "biforme", em grego, essa palavra pode ser transposta, em português, para o gênero masculino. Ela pertence ao vocabulário militar, designando funçōes exercidas, conseqüentemente, por um homem: Sýmmakhos é o auxiliar nas batalhas, pelejando ombro a ombro cơm outro soldado, no corpo a corpo com o inimigo. (Posteriormente, o termo significará aliado, forma abstrata que, vertida para o feminino, aparece em traduçōes que enfraquecem a violência do original grego).

Se nos lembrarmos de que esses versos demarcam a prece de um herói combatente, percebemos, com alguma surpresa, que a Afrodite Guerreira já estava presente na Invocação; e que todas as suas açõés têm as características de uma estratégia militar: ela trabalha para derrubar um inimigo, para reverter o quadro de um combate. O que Safo de Lesbos implora à deusa parece não ser muito diferente do que Diomedes deseja: Faze com que eu mate esse homem, traze-o ao alcance de minha lança, ele que me tocou primeiro e disto se ufanal

Constatando que o poema desemboca numa Invocação, somos tentados a pensar na figura do círculo: uma linha que gira para seu ponto de partida. Imagem eficaz: mas somente se continuarmos a refletir em termos de um tempo vetorizado. 
As palavras, na Ode a Afrodite, são como os gestos de um dançarino; a temporalidade que rege os signos é a da música. As cadeias vocabulares irradiam: sonoridades, sentidos; cada movimento está presente aos outros movimentos - e É único. As significações são construídas no interior do texto e reenviam para a História, o grande contexto da cultura grega: Homero. Suas personagens, suas fórmulas, sua disciplina métrica. Seu universo aristocrático. Safo de Lesbos, poeta, é um dançarino acorrentado:

"Dançar em cadeias: Diante de cada artista, poeta e escritor grego, deve-se perguntar: qual é a nova coaçāo que ele se impōe e torna atraente para seus contemporâneos (de modo que encontra imitadores)? Pois o que se denomina 'invenção' (na métrica, por exemplo) é sempre um tal grilhão autoimposto. 'Dançar em cadeias', tornar as coisas difíceis para si e em seguida estender sobre elas a ilusão da facilidade - essa é a habilidade que eles querem nos mostrar. Já em Homero percebe-se uma grande quantidade de fórmulas herdadas e leis épicas de narrativa, dentro das quais ele tinha de dançar: ele próprio criou novas convenções para os que viriam. Esta era a escola de educação dos poetas gregos" (Nietzsche, "O andarilho e sua sombra", 140).

Por um desses acasos inverossímeis, fechamos nosso volume de filosofia, abrindo Homero ao acaso, num momento de combate:

Versos 297 e seguintes da Ilíada. Campos de guerra. Afrontamento entre gregos e troianos. Afrodite tenta proteger seu filho Enćias, caído por terra, com os tendōes destroçados. Diomedes a persegue, e - com um toque impiedoso da lança - fere a deusa do amor; na carne do punho, acima da palma da mão. Lançando um grito, ela deixa cair seu filho, e é forçada a ouvir as injúrias de Diomedes: Deixa, ó filha de Zeus, a guerra e a camificina. Já nāo basta que tu estejas sempre seduzindo as fracas mulheres? Ainda achas que podes enfrentar os combates? Doravante, creio que vais estremecer com as batalhas, mesmo que aconteçam longe de ti.

Abandonando o combate, a deusa sobe até o Olimpo, onde é socorrida, mas tem que fazer à ironia de Palas Atena e de Hera: com certeza Afrodite teria tentado convencer alguma menina grega a seguir os troianos... Com certeza, foi ao acariciar uma grega de belos véus que ela machucou a mão, num broche de ouro...

Ouvindo essas palavras, Zeus Portador da Egide consola a deusa do amor: Não competem a ti, minha filha, os trabalhos guerreiros. Deves presidir ds delicias do casamento. Ares e Atena vão se ocupar dos combates.

Essa deusa delicada e inconseqüente - feminina - reaparece, completamente transformada, nos versos de Safo de Lesbos. Ao assumir um papel no drama vivido pelo Poeta, ao envergar as armas do sýmmakhos, ela transfere para o discurso amoroso a dignidade do registro épico; infunde nas palavras do Suplicante apaixonado a respiração tensa das oraçōes guerreiras, o ruído das armas e o zunir das flexas - os corpos entregues aos combates singulares.

A Illada é o pano de fundo desses versos? Não. Igual a Afrodite, ela está presente em cada signo: afirmada e negada. Sem que exista um movimento "dialético": num ritmo de dança, ouvimos, juntos, o obscuro passado guerreiro e o presente, com seus novos valores; o registro épico, tradicional, e a novidade das vozes líricas. Homero e Safo. 
Nesse cruzamento de falas, o poema é um combate, no campo das palavras. Seguramente, com Homero, o Pai dos Poetas. Mas, através dele, com Afrodite. Do fundo da agonia, brota uma voz melodiosa: Safo de Lesbos enverga a máscara de Tecelã de Signos e, astuciosa, lança uma rede sobre a deusa do Amor, cujos gestos e discursos são contaminados pela urgência do Suplicante: "prontamente chegaram..." ... "Logo, ela perseguirá..." "Logo, presentes ofertará..." Os versos estremecem; Safo e Afrodite combatem lado a lado.

\section{Notas}

1- Cf. "Life of Dionysius", in: Diontsios de Halicarnasso, 1968.

2- "Sobre a disposiço das palavras", 23, in: Dion. Halic. 1985.

3- Garrett, "Ode a Vênus", in: Haddad, 1942:19-20.

4- Tradução de Aubreton, 1968:223.

5- Odisséia, XI, 489 e sq.: "Ne me console pas de la mort, illustre Ulysse. J'aimerais mieux, en vivant sur la glèbe, être aux gages d'autrui chez un homme pauvre et sans grandes ressources, que de regner sur le peuple évanoui des morts". (Tradução de Meunier, 1961).

6- F. B. J. Kuiper propōe para o cognato óvía o étimo *an-is-ya. Cf. sânscrito anista, "funesto" (Chantraine, 1984).

\section{Referências Bibliográficas}

ARISTÓTELES. Ethique de Nicomaque (trad. de Jean Voilquin). Paris: Garnier, s/d.

AUBRETON, R. Introdução a Homero. Sāo Paulo: Difel/Edusp, 1968.

BONNARD, A. A civilizaço grega (trad. de José Saramago). São Paulo: Martins Fontes, 1980.

BOWIE, A.M. The poetic dialect of Sappho and Alcaeus. Tese de Doutorado. Cambridge, 1979.

BOWRA, C.M. Greek lyric poetry. Oxford: Clarendon, 1961.

DIONISIOS DE HALICARNASSO. The critical essays (bilingüe; trad. de Stephan Usher). London: The Loeb Classical Library, 1985, 2.vol.

DIONISIOS DE HALICARNASSO. The roman antiquities (bilingüe; trad. de Stephan Usher). London: The Loeb Classical Library, 1968, $7 \mathrm{vol}$.

EURIPIDES. Hipólito, in Euripides IV (bilingüe; trad. de A. S. Way). London: The Loeb Classical Library, 1980.

FRÄNKEL, H. Early Greek poetry and philosophy, Oxford: Basil Blackwell, 1975.

GARRETT, A. "Ode a Vênus". In HADDAD, J.A. Safo: Lírica. Sāo Paulo: Ediçōes Cultura, 1942, p. 19-20.

HADDAD, J.A. Safo: Lírica. Sāo Paulo: Ediçōes Cultura, 1942. 
HINO HOMERICO A AFRODITE, in The homeric hymns and homerica (bilingüe; trad. de Evelyn-White). London: The Loeb Classical Library, 1959, p. 406427.

HOMERO. Iliade (texto estab. e trad. por Paul Mazon). Paris: Les Belles Lettres, 1949, 4 vol.

HOMERO. Odyssée (trad. de Mario Meunier). Paris: Albin Michel, 1961.

HOMERO. The Odyssey (bilingüe; trad. de A.T. Murray). London: The Loeb Classical Library, 1945, 2 vol.

JAEGER, W. El origen de la doctrina de la divinidad del alma. In La teologia de los primeros filósofos griegos. trad. de José Gaos). México: Fondo de Cultura Económica, 1982, p. 77-92.

LOBEL, Е. ГАПФОY Oxford: Clarendon, 1925.

LOBEL, E. e PAGE. D. Poetarum lesbionum fragmenta. Oxford: Clarendon, 1955.

NIETZSCHE, F. O andarilho e sua sombra, in Obras Incompletas (trad. e notas de Rubens Rodrigues Torres Filho). São Paulo: Abril Cultural, 1978 (col. "Os Pensadores").

PAGE, D. Sapho and Alcaeus. Oxford: Clarendon, 1961.

PINDARO. Odas (trad. e notas de Ipandro Acaico). México: S.E.P., 1984.

PINDARO. The Odes (bilingüe; trad. de Sir John Sandys). London: The Loeb Classical Library, 1957.

PINDARO. Oeuvres completes (bilingüe; trad. de J.P. Savignac). Paris: Editions de la Différence, 1990.

POUND, E. A arte da poesia (trad. de Heloísa Lima e José Paulo Paes). São Paulo: Cultrix/Edusp. 1976.

TAYLOR, A.E. El pensamiento de Sócrates (trad. de Mateo Hernández Barroso). México: Fondo de Cultura Económica, 1985.

FONTES, J. B. Lourdisseuse de trames. Classica, São Paulo, 5/6: 69-82, 1992/1993.

RESUME: Comme un mourant, le Poète s'adresse à la divinité et

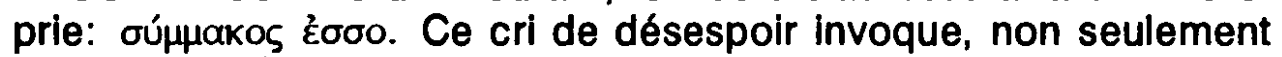
l'alliée, mot en quelque sorte abstrait, mais aussi, et surtout. celui (celle) qui assiste quelqu'un dans un combat, et nous invite à relire un poème de Sapho (plus connu sous le nom d'Ode à Aphrodite) a travers la trame du lexique des combats: prise dans la tessiture du chant, Aphrodite s'avance, dans le champ de bataille, à côté de l'amoureux.

MOTS CLÉS: Sapho, Aphrodite, lyrique grecque, littérature grecque, Grèce. 